\title{
Characterization of the Murine Cytomegalovirus Early Transcription Unit e1 That Is Induced by Immediate-Early Proteins
}

\author{
BRIGITTE BÜHLER, ${ }^{1}$ GÜNTHER M. KEIL, ${ }^{2}$ FRANK WEILAND, ${ }^{2}$ AND ULRICH H. KOSZINOWSKI ${ }^{1 *}$ \\ Department of Virology, Institute for Microbiology, University of Ulm, $7900 \mathrm{Ulm},{ }^{1}$ and Federal Research Centre for \\ Virus Diseases of Animals, 7400 Tübingen, ${ }^{2}$ Federal Republic of Germany
}

Received 28 June 1989/Accepted 3 January 1990

\begin{abstract}
The regulation of murine cytomegalovirus early $(E)$ gene expression was studied in the cell line B25, which is stably transfected with the immediate-early ie1/ie 3 gene complex. Infection of $B 25$ cells in the presence of the protein synthesis inhibitor cycloheximide resulted in the expression of some $\mathbf{E}$ genes, whereas for the expression of other $\mathbf{E}$ genes prior protein synthesis was still mandatory, thus showing differences in the expression requirements of individual $\mathbf{E}$ genes. Transcription unit $\mathbf{e 1}$, a member of the $\mathbf{E}$ genes induced by immediateearly products of the ie1/ie3 gene complex, was characterized. It is located between map units 0.709 and 0.721 of the genome of murine cytomegalovirus strain Smith. A 2.6-kilobase RNA specified in this region is spliced from three exons of 912, 177, and 1,007 or 1,020 nucleotides, which are separated by introns of 93 and 326 nucleotides. The second AUG located in the first exon 119 nucleotides downstream of the 5 ' cap site is followed by an open reading frame of 990 nucleotides. The predicted polypeptide of 330 amino acids has a calculated molecular mass of 36.4 kilodaltons. Transfection with e1 revealed three antigenically related proteins of 36, 37, and 38 kilodaltons; these proteins probably represent differently modified forms of the predicted protein. These three proteins are phosphorylated and are associated with intranuclear inclusion bodies. A 33-kilodalton protein also derived from el was identified as a product of nonspliced transcripts. Comparison of amino acid sequences revealed homology between the murine cytomegalovirus transcription unit e1 and a human cytomegalovirus $\mathbf{E}$ transcription unit.
\end{abstract}

As in other herpesviruses, the expression of genes from the 235-kilobase-pair DNA genome of murine cytomegalovirus (MCMV) is temporally controlled and regulated in a cascade fashion (17). At least three kinetic classes of MCMV genes can be differentiated: immediate early (IE) or $\alpha$, early (E) or $\beta$, and late or $\gamma$. Previous work has led to the identification of the major MCMV IE genes ie1, ie2, and ie3, their transcripts, and translation products (18-20). The transcription of these genes is controlled by a promoter-regulatory region with cis-acting enhancer elements that is located in the HindIII L fragment of the MCMV genome (8). Genes ie 1 and ie 3 are transcribed from the HindIII L fragment and the adjoining HindIII $\mathrm{K}$ fragment (see Fig. 7). The ie1/ie3 complex encodes five exons. The ie 1 transcripts are spliced from exons 1 through 4 (18), whereas ie3 transcripts are produced from exons $1,2,3$, and 5 (M. Messerle, personal communication). Gene ie 2 is transcribed in the opposite direction and is almost completely located in HindIII L. A role of the IE proteins during virus replication and as antigens in the protective immune response to infection has been documented $(6,30$; U. H. Koszinowski, M. Del Val, and M. J. Reddehase, Curr. Top. Microbiol., in press).

Whereas transcription in the IE phase is restricted to distinct regions of the genome, transition to the $E$ phase is associated with transcription from all along the genome (17, 24). Synthesis of several $E$ proteins has been demonstrated $(17,20,25,38)$, but no MCMV E gene has been characterized. Previous experiments have revealed that initiation of the $E$ phase of viral gene expression requires preceding IE protein synthesis (17). This does not necessarily imply that the expression of all E genes is regulated by IE proteins. The question of whether all $\mathrm{E}$ genes are subject to the same mode of regulation can be approached by infection of transfected

\footnotetext{
* Corresponding author.
}

cell lines that express IE proteins constitutively. Constitutive expression of proteins encoded by the IE ie1/ie 3 gene complex (19) proved to be sufficient for the expression of one subclass of $E$ genes, whereas expression of further $E$ genes was only seen after de novo synthesis of other viral proteins. An $\mathrm{E}$ transcription unit belonging to the first subclass of $\mathrm{E}$ genes was characterized.

\section{MATERIALS AND METHODS}

Virus and cell culture. MCMV (mouse salivary gland virus strain Smith; ATCC VR-194) was propagated on BALB/c mouse embryonal fibroblasts (MEF) and purified as previously described (17). BALB/c 3T3 cells and clonal derivatives thereof were maintained in Dulbecco modified Eagle medium supplemented with $10 \%$ (vol/vol) fetal calf serum, 2 $\mathrm{mM}$ L-glutamine, $100 \mu \mathrm{g}$ of streptomycin per $\mathrm{ml}$, and $100 \mathrm{U}$ of penicillin per $\mathrm{ml}$. Cells were infected with $20 \mathrm{PFU}$ per cell by using the technique of centrifugal enhancement of infectivity at $800 \times g$ for $30 \mathrm{~min}$. Cells were labeled with $150 \mu \mathrm{Ci}$ of $\left[{ }^{35}\right.$ S]methionine (Amersham, Braunschweig, Federal Republic of Germany) per ml of methionine-free medium. To inhibit transcription and translation, dactinomycin (ActD; 5 $\mu \mathrm{g} / \mathrm{ml})$ and cycloheximide $(50 \mu \mathrm{g} / \mathrm{ml})$ were added.

Transfection and selection of transfectants. Monolayers of BALB/c 3T3 cells were transfected with plasmid DNA by using the calcium phosphate precipitation technique. To establish cell lines that express ie $1 / i e 3$ gene products, $10 \mu \mathrm{g}$ of pAMB25 containing the ie $1 / \mathrm{ie} 3$ gene complex (19) and 1 $\mu \mathrm{g}$ of pAG60 providing the kanamycin-neomycin resistance gene were coprecipitated and added in $0.5-\mathrm{ml}$ precipitates to $10^{6}$ cells. Isolation of geneticin (G418)-resistant clones was carried out by standard procedures (21). Selected clones were tested for IE gene expression by indirect immunofluorescence with monoclonal antibody (mAb) MCMV-6/58/1 directed against the MCMV IE protein pp89 (20). 
Stably transfected cell lines expressing e1 gene products were established by cotransfection with plasmids pBB2.9, which contains the e1 gene region, and pAG60 by selection with G418 and by screening with $\mathrm{mAb} 20 / 234 / 28$.

Antisera and mAbs. Antisera and $m A b s$ were produced essentially as described previously (20). In brief, BALB/c mice were immunized three times at 14-day intervals with lysates of $2 \times 10^{7}$ sonicated cells, which were harvested at 10 $h$ postinfection (p.i.), that is, during the $E$ phase of the MCMV replication cycle. For the first and second subcutaneous injections, lysates in phosphate-buffered saline (PBS) were made up in the same volume of Freund complete adjuvant and Freund incomplete adjuvant, respectively. The last immunization was given by the intraperitoneal route. Then, 3 to 4 days later, splenocytes were isolated and fused at a ratio of $1: 1$ with SP2/0-Ag14 myeloma cells. After selection in hypoxanthine-aminopterin-thymidine medium, hybridomas were screened by indirect immunofluorescence for the production of antibodies against $\mathrm{E}$ proteins. Positive hybridomas were cloned twice by limiting dilution.

In the present study, mAb 20/234/28 (immunoglobulin G1 [IgG1]), recognizing nuclear $\mathrm{E}$ proteins of 36 to 38 kilodaltons (kDa), and mAb 20/357/4 (IgG1), recognizing cytoplasmic $\mathrm{E}$ proteins of 53 and $69 \mathrm{kDa}$, were used.

Immunofluorescence. Cells were fixed for 20 min with $3 \%$ (wt/vol) paraformaldehyde in PBS and for 10 min with $3 \%$ paraformaldehyde in PBS containing $0.1 \%$ ( $\mathrm{vol} / \mathrm{vol}$ ) Triton $\mathrm{X}-100$. Indirect immunofluorescence was carried out with $\mathrm{mAb} 20 / 234 / 28$ and fluorescein-conjugated $\mathrm{F}\left(\mathrm{ab}^{\prime}\right)_{2}$ fragments of goat anti-mouse IgG (Dianova, Hamburg, Federal Republic of Germany). For the visualization of cell nuclei by staining of the DNA, cells were incubated for 5 min with $1 \mu \mathrm{g}$ of Hoechst dye 33258 (Serva, Heidelberg, Federal Republic of Germany) per ml of PBS.

Immunocolloidal gold electron microscopy. MCMVinfected MEF were fixed with freshly prepared $2 \%(\mathrm{wt} / \mathrm{vol})$ paraformaldehyde and $0.02 \%(\mathrm{wt} / \mathrm{vol})$ glutaraldehyde in PBS. After a rinse with $50 \mathrm{mM}$ glycine in the same buffer, cells were gently scraped off, collected by centrifugation, and embedded in $1 \%(\mathrm{wt} / \mathrm{vol})$ agarose. Cell pellets were treated stepwise with sucrose from 0.3 to $2.2 \mathrm{M}$, placed on copper stubs, and frozen by immersion in liquid nitrogen. Ultrathin frozen sections were prepared at $-100^{\circ} \mathrm{C}$ with an ultracut microtome equipped with the cryocut attachment (Reichert, Nussloch, Federal Republic of Germany) and transferred with sucrose on 200-mesh hexagonal copper grids. For immunostaining, sections were incubated sequentially at $20^{\circ} \mathrm{C}$ with $\mathrm{mAb} 20 / 234 / 28$, rabbit anti-mouse IgG (Cooper Biomedical, Inc., West Chester, Pa.), and protein A-colloidal gold particles $10 \mathrm{~nm}$ in diameter (Dianova) in $0.2 \%(\mathrm{wt} / \mathrm{vol})$ gelatin in PBS. After sections were rinsed with PBS and distilled water, they were stained with uranyl

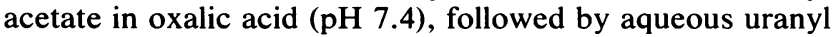
acetate of low $\mathrm{pH}$.

Immunoprecipitation. Immunoprecipitation, $10 \%$ (wt/vol) sodium dodecyl sulfate-polyacrylamide gel electrophoresis, and fluorography were carried out as previously described (20). In brief, samples of cell lysates equivalent to $10^{5}$ cells were incubated with $5 \mu \mathrm{l}$ of anti-MCMV serum or with $3 \mu \mathrm{l}$ of ascitic fluid derived from hybridoma $20 / 234 / 28$ or $20 / 357 / 4$. Because mouse immunoglobulin IgG1 does not bind to protein A, a $10 \%$ (wt/vol) suspension of fixed Staphylococcus aureus was preincubated with rabbit antibodies specific for mouse IgG (Dianova) before addition to the antigenantibody complexes.

Western blotting (immunoblotting). Samples of lysates equivalent to $10^{6}$ cells were prepared as for immunoprecipitation. The polypeptides of the cell lysates or $50 \mu \mathrm{g}$ of virion-associated polypeptides was separated by $10 \%$ sodium dodecyl sulfate-polyacrylamide gel electrophoresis and transferred electrophoretically to nitrocellulose. Immunostaining of the transferred proteins was performed with anti-MCMV serum and mAb 20/234/28 as previously described (20).

Plasmids. The construction of recombinant plasmid pBB2.9 followed established methods (19). For preparation of this plasmid, an XbaI-PstI MCMV DNA fragment (map units 0.709 to 0.721 ) was isolated from plasmid clone pAMB84-5 (9) and inserted into plasmid vector pSP65.

Isolation of RNA and Northern (RNA) blot hybridization. Preparation of whole-cell RNA, gel electrophoresis, and transfer to nitrocellulose were done as described previously (17). DNA probes used for hybridization were labeled with $\left[\alpha-{ }^{32}\right.$ P]dCTP by using the multiprime DNA labeling system of Amersham. ${ }^{32} \mathrm{P}$-labeled cRNA was transcribed in vitro by SP6 RNA polymerase (19). For estimation of RNA sizes, Escherichia coli $16 \mathrm{~S}$ and 23S rRNAs (Boehringer GmbH, Mannheim, Federal Republic of Germany) and $18 \mathrm{~S}$ and $28 \mathrm{~S}$ mouse rRNA were used as standard size markers.

Hybrid selection and in vitro translation of RNA. Hybrid selection of RNA by MCMV DNA fragments and in vitro translation were performed as previously described (20).

Nuclease protection experiments. Whole-cell RNA was hybridized to end-labeled MCMV DNA fragments and digested with $\mathrm{S} 1$ nuclease or hybridized to evenly labeled cRNA, which was transcribed in vitro by SP6 RNA polymerase, and digested with RNases $A$ and $T_{1}$. Nucleaseresistant fragments were size fractionated on denaturing sequencing gels (19).

Primer extension. Primer extension was carried out as reported by Bertholet et al. (1). Samples of $5 \mu \mathrm{g}$ of whole-cell RNA and $1 \mathrm{ng}$ of $5^{\prime}$-end-labeled DNA fragments were coprecipitated with ethanol and suspended in $15 \mu \mathrm{l}$ of hybridization buffer containing $80 \%$ ( $\mathrm{vol} / \mathrm{vol}$ ) formamide, 400 $\mathrm{mM} \mathrm{NaCl}, 40 \mathrm{mM}$ PIPES [piperazine- $N, N^{\prime}$-bis(2-ethanesulfonic acid)] (pH 6.4), and 1 mM EDTA. After heating for $5 \mathrm{~min}$ at $90^{\circ} \mathrm{C}$, samples were incubated for $12 \mathrm{~h}$ at $44^{\circ} \mathrm{C}$ to allow for hybridization of the RNA to the DNA fragments. For reverse transcription, nucleic acids were precipitated with ethanol, suspended in $20 \mu$ l of a reaction mixture containing $100 \mathrm{mM}$ Tris (pH 8.3), $150 \mathrm{mM} \mathrm{KCl}, 10 \mathrm{mM}$ $\mathrm{MgCl}_{2}, 10 \mathrm{mM}$ dithiothreitol, $500 \mu \mathrm{M}$ deoxynucleoside triphosphates, $25 \mathrm{U}$ of human placental RNase inhibitor, and $15 \mathrm{U}$ of reverse transcriptase, and incubated at $42^{\circ} \mathrm{C}$. After 1 $h$, nucleic acids were precipitated with ethanol and size fractionated by electrophoresis on denaturing sequencing gels.

Sequence analysis of DNA. DNA sequences were determined by the method of Maxam and Gilbert with the modifications reported previously (18). Single end-labeled DNA fragments were prepared by strand separation or by restriction enzyme cleavage.

\section{RESULTS}

E genes differ in their expression requirements. The expression of $\mathrm{E}$ genes requires the preceding synthesis of IE proteins (16). When cells are infected in presence of the protein synthesis inhibitor cycloheximide $(\mathrm{CH})$, de novo synthesis of viral proteins is prevented and only IE genes are transcribed. After replacement of $\mathrm{CH}$ by the RNA synthesis inhibitor ActD these transcripts are translated, whereas at 


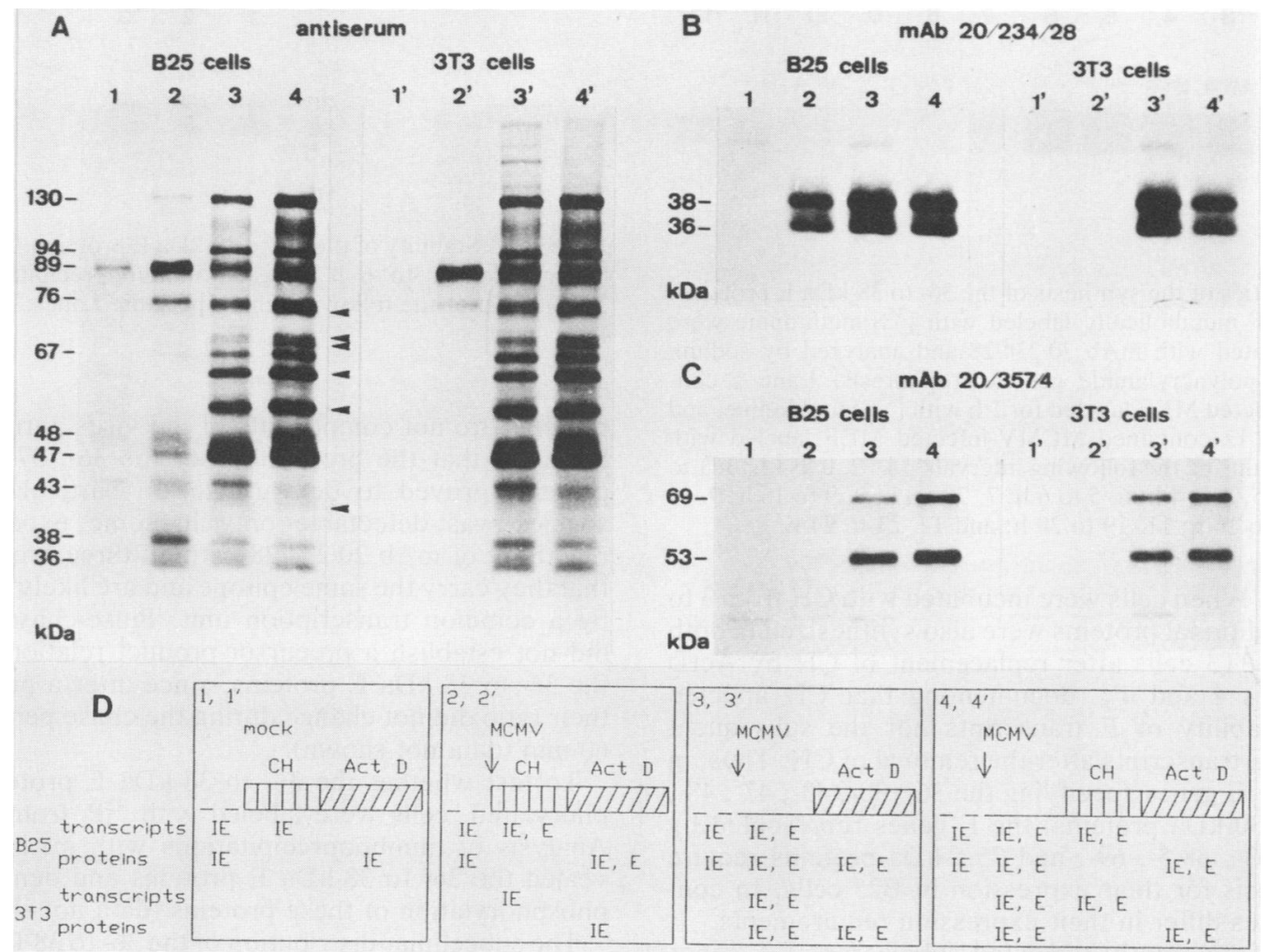

FIG. 1. MCMV E genes differ in their expression requirements. E-gene expression was studied by immunoprecipitation of viral proteins from BALB/c 3T3 B25 cells stably transfected with the MCMV ie1/ie3 gene complex (A through C, lanes 1 through 4) and infected with MCMV. Immunoprecipitation of viral proteins from the parental cell line BALB/c 3T3 served for comparison (A through C, lanes 1' through $\left.4^{\prime}\right)$. Lysates of B25 and 3T3 cells labeled with $\left[{ }^{35}\right.$ S $]$ methionine as described below were immunoprecipitated with murine MCMV antiserum (A), mAb 20/234/28 (B), or mAb 20/357/4 (C) and analyzed by sodium dodecyl sulfate-polyacrylamide gel electrophoresis. Lanes: 1 and 1', mock-infected cells incubated with $\mathrm{CH}$ that was replaced after $3 \mathrm{~h}$ by ActD and ${ }^{35}$ S $]$ methionine; 2 and $2^{\prime}$, MCMV-infected cells incubated from 0 to $3 \mathrm{~h}$ p.i. with $\mathrm{CH}$ and from 3 to $7 \mathrm{~h}$ p.i. with ActD and $\left[{ }^{35} \mathrm{~S}\right]$ methionine; 3 and $3^{\prime}$, MCMV-infected cells incubated from 3 to $7 \mathrm{~h}$ p.i. with ActD and ${ }^{35}$ S]methionine; 4 and $4^{\prime}$, MCMV-infected cells incubated from 3 to $6 \mathrm{~h}$ p.i. with $\mathrm{CH}$ and from 6 to $10 \mathrm{~h}$ p.i. with ActD and $\left[{ }^{35}\right.$ S]methionine. E proteins of the second subclass are marked by arrowheads. (D) Experimental regimen that was employed for studying the expression requirements of $E$ genes. The indicated viral gene products were synthesized in the used cell lines under the different infection conditions.

the same time any further transcription is blocked. This means that under these conditions only IE proteins are synthesized, whereas the expression of $E$ genes is precluded. When the same experimental regimen is applied to cells that already express IE proteins constitutively, these IE proteins may activate transcription of $E$ genes in the presence of $\mathrm{CH}$. E transcripts synthesized during this period will then be translated to E proteins after replacement of $\mathrm{CH}$ by ActD.

The preparation of transfectant L-cell lines that constitutively express MCMV IE proteins has been reported (21). Since L-cells turned out to be refractory to MCMV infection, BALB/c 3T3 cells were used for transfection to establish cell lines that are permissive for infection and that express IE proteins constitutively. Transfection was performed with plasmid pAMB25 containing the ie1/ie 3 gene complex (19). A stably transfected cell line, referred to as B25, was selected that expresses the major IE protein pp89, as demonstrated by indirect immunofluorescence and by immunoprecipitation with mAb MCMV-6/58/1.

The induction of $\mathrm{E}$ gene expression by IE proteins was studied by immunoprecipitation of viral proteins from B25 cells (Fig. 1A through $C$, lanes 1 through 4), and, as a control, from the parental BALB/c 3T3 cells (Fig. 1A through $\mathrm{C}$, lanes $1^{\prime}$ through $4^{\prime}$ ). Immunoprecipitation with antiserum revealed the major IE protein pp89 and its posttranslationally processed derivative pp76 (20) in B25 cells but not in the 3T3 cells (Fig. 1A, lanes 1 and $1^{\prime}$ ). After infection in the presence of $\mathrm{CH}$ that was replaced at $3 \mathrm{~h}$ p.i. by ActD, as to be expected, IE proteins pp89 and pp76 could be seen in both cell lines, but in B25 cells additional proteins of $36,38,43,47,48,67,94$, and $130 \mathrm{kDa}$ were then synthesized that were absent from 3T3 cells (Fig. 1A, lanes 2 and $2^{\prime}$ ). When B25 and 3T3 cells were infected in the absence of inhibitors and ActD was added at $3 \mathrm{~h}$ p.i., the 36-, 38-, 43-, 47-, 48-, 67-, 94-, and 130-kDa proteins, seen before only in B25 cells, were now detected in both cell lines (Fig. $1 A$, lanes 3 and $3^{\prime}$ ). This demonstrates that the $E$ genes represented by these proteins require for their expression only IE proteins encoded by the transfected ie $1 / \mathrm{ie} 3$ gene complex.

In addition to the 36-, 38-, 43-, 47-, 48-, 67-, 94-, and $130-\mathrm{kDa}$ proteins found in B25 cells after reversal of the $3-\mathrm{h}$ $\mathrm{CH}$ block, proteins of $42,53,63,68.5,69$, and $75.5 \mathrm{kDa}$ were synthesized in B25 and 3T3 cells that were infected in the absence of $\mathrm{CH}$ (arrowheads in Fig. 1A, lanes 3 and 3'). The possibility that the period of $3 \mathrm{~h}$ in the presence of $\mathrm{CH}$ was too short to allow the transcription of the RNAs encoding these additional proteins was excluded, because a 3-h period of transcription in the absence of $\mathrm{CH}$ led to the synthesis of 


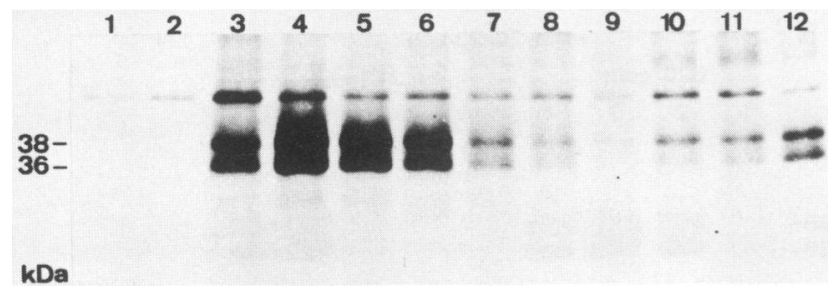

FIG. 2. Kinetics of the synthesis of the 36- to 38-kDa E proteins. Lysates of MEF metabolically labeled with $\left[{ }^{35}\right.$ S $]$ methionine were immunoprecipitated with mAb 20/234/28 and analyzed by sodium dodecyl sulfate-polyacrylamide gel electrophoresis. Lane 1 contained mock-infected MEF labeled for $1 \mathrm{~h}$ with $\left[{ }^{35} \mathrm{~S}\right]$ methionine, and lanes 2 through 12 contained MCMV-infected MEF labeled with $\left[{ }^{35} \mathrm{~S}\right]$ methionine during the following intervals p.i.: 2,0 to $1 \mathrm{~h} ; 3,1$ to $2 \mathrm{~h} ; 4,2$ to $3 \mathrm{~h} ; 5,3$ to $4 \mathrm{~h} ; 6,5$ to $6 \mathrm{~h} ; 7,7$ to $8 \mathrm{~h} ; 8,9$ to $10 \mathrm{~h} ; 9,11$ to $12 \mathrm{~h} ; 10,15$ to $16 \mathrm{~h} ; 11,19$ to $20 \mathrm{~h}$; and 12,23 to $24 \mathrm{~h}$.

these proteins. When cells were incubated with $\mathrm{CH}$ from 3 to $6 \mathrm{~h}$ p.i., the additional proteins were also synthesized in both B25 cells and 3T3 cells after replacement of $\mathrm{CH}$ by ActD (Fig. 1A, lanes 4 and $4^{\prime}$ ), documenting that $\mathrm{CH}$ affected neither the stability of $\mathrm{E}$ transcripts nor the subsequent translation of $\mathrm{E}$ transcripts after the removal of $\mathrm{CH}$. Thus, in contrast to the $\mathrm{E}$ genes specifying the 36-, 38-, 43-, 47-, 48-, 67-, 94- and 130-kDa proteins, the $E$ genes represented by the 42-, 53-, 63-, 68.5-, 69-, and 75.5-kDa proteins require protein synthesis for their expression in B25 cells. In conclusion, $\mathrm{E}$ genes differ in their expression requirements.

Examples of differently regulated subclasses of $E$ genes can be provided by immunoprecipitation of $E$ proteins with mAbs. The mAb 20/234/28 precipitated the 36-, 37-, and 38-kDa E proteins; IE proteins expressed in B25 cells proved sufficient for the synthesis of these E proteins (Fig. 1B). On the other hand, mAb 20/357/4 precipitated proteins of 53 and $69 \mathrm{kDa}$ that were representatives of the second subclass of $\mathrm{E}$ genes (Fig. 1C).

Molecular characteristics and intracellular distribution of the 36- to 38-kDa $\mathbf{E}$ proteins. As an example of $\mathrm{E}$ proteins whose expression is controlled by the IE ie $1 /$ ie 3 gene complex, the 36- to $38-\mathrm{kDa} \mathrm{E}$ proteins and their coding region were characterized. The kinetics of the synthesis of the 36to $38-\mathrm{kDa} \mathrm{E}$ proteins was studied in murine embryonal fibroblasts by metabolic labeling during different times after infection (Fig. 2). The $\mathrm{E}$ phase is initiated at about $2 \mathrm{~h}$ p.i. and is terminated by viral DNA replication at about $16 \mathrm{~h}$ p.i. (17). The 36- to 38-kDa E proteins were detectable by $2 \mathrm{~h}$ p.i. (Fig. 2, lane 3). Up to $6 \mathrm{~h}$ p.i. they were synthesized at a high level (Fig. 2, lanes 3 through 6). Thereafter synthesis drastically decreased (Fig. 2, lanes 7 through 9). During late times there was some synthesis (Fig. 2, lanes 10 through 12), perhaps due to a de novo infection of some cells.

The stability of the $36-$ to $38-\mathrm{kDa} E$ proteins was determined. Cells were labeled with $\left[{ }^{35} \mathrm{~S}\right]$ methionine from 1 to $6 \mathrm{~h}$ p.i. and incubated without radioactive methionine for 0,4 , and $18 \mathrm{~h}$. A high stability of the $36-$ to $38-\mathrm{kDa}$ E proteins was indicated by the finding that these polypeptides remained detectable without signs of degradation during the entire chase period of $18 \mathrm{~h}$ (Fig. 3, lane 3).

The association of the 36- to 38-kDa proteins with virions was studied by Western blot analysis. The antiserum recognized a number of viral proteins in lysates of infected cells and in purified virions (Fig. 4a, lanes 2 and 3). The 36-, 37-, and $38-\mathrm{kDa} \mathrm{E}$ proteins were only detectable in lysates of infected cells (Fig. 4a, lane 2). The same result was obtained with mAb 20/234/28 (Fig. 4b). This indicated that these

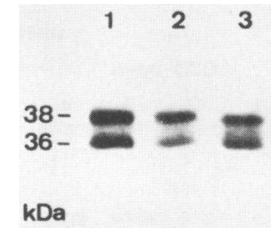

FIG. 3. Stability of the 36- to 38-kDa E proteins. Lysates of MEF labeled from 1 to $6 \mathrm{~h}$ p.i. and immunoprecipitated with $\mathrm{mAb}$ 20/234/28 after the following chase periods. Lanes: $1,0 \mathrm{~h} ; 2,4 \mathrm{~h} ; 3$, $18 \mathrm{~h}$.

proteins are not components of the virus particle. It should be noted that the proportions of the 36-, 37-, and $38-\mathrm{kDa}$ proteins proved to be variable. In particular the $37-\mathrm{kDa}$ species was detectable only in some experiments. The reactivity of $\mathrm{mAb} 20 / 234 / 28$ with all three proteins suggests that they carry the same epitope and are likely to be encoded by a common transcription unit. Pulse-chase experiments did not establish a precursor-product relationship between the 36- to 38-kDa E proteins, since after a pulse of $15 \mathrm{~min}$ their ratio did not change during the chase period from 15 to 60 min (data not shown).

To test whether the $36-$ to $38-\mathrm{kDa} \mathrm{E}$ proteins are phosphorylated, cells were labeled with ${ }^{32} \mathrm{P}_{i}$ from 1 to $6 \mathrm{~h}$ p.i. Analysis of immunoprecipitations with mAb 20/234/28 revealed the $36-$ to $38-\mathrm{kDa} \mathrm{E}$ proteins and demonstrated the phosphorylation of these proteins (data not shown).

The subcellular distribution of the $36-$ to $38-\mathrm{kDa} \mathrm{E}$ proteins was examined by indirect immunofluorescence (Fig. 5). By 6 h p.i., infected cells showed a faint nuclear staining with speckles of bright fluorescence (Fig. 5a). By $10 \mathrm{~h}$ p.i., the sizes of the speckles increased, but the number of speckles decreased (Fig. 5b). By 24 h p.i. a large area in each cell nucleus was intensively stained (Fig. 5c). The pattern of nuclear fluorescence resembled the distribution of inclusion bodies, which are found in the nuclei of MCMV-infected cells (40), and hence suggested an association of the 36- to 38-kDa E proteins with these structures. Electron microscopic examination after immunocolloidal gold staining doc-

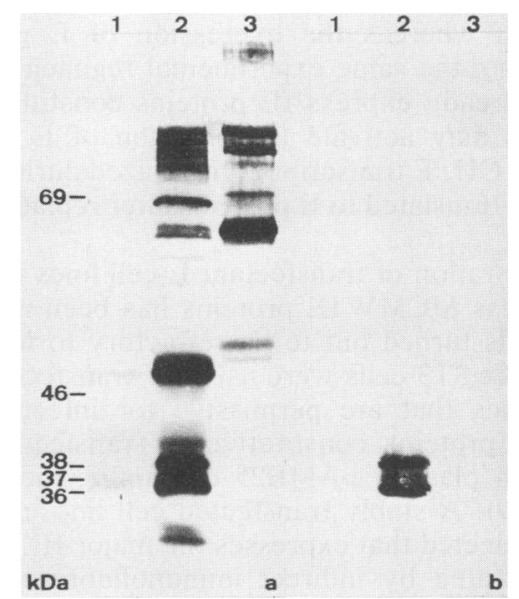

FIG. 4. The 36- to 38-kDa $\mathrm{E}$ proteins are not associated with virions. Proteins in MEF lysates or of purified virions were separated by sodium dodecyl sulfate-polyacrylamide gel electrophoresis and analyzed by Western blotting with antiserum (a) and mAb 20/234/28 (b). Lanes: 1, mock-infected MEF; 2, MCMV-infected $\mathrm{MEF}$ at $24 \mathrm{~h}$ p.i.; 3, virion-associated proteins. 

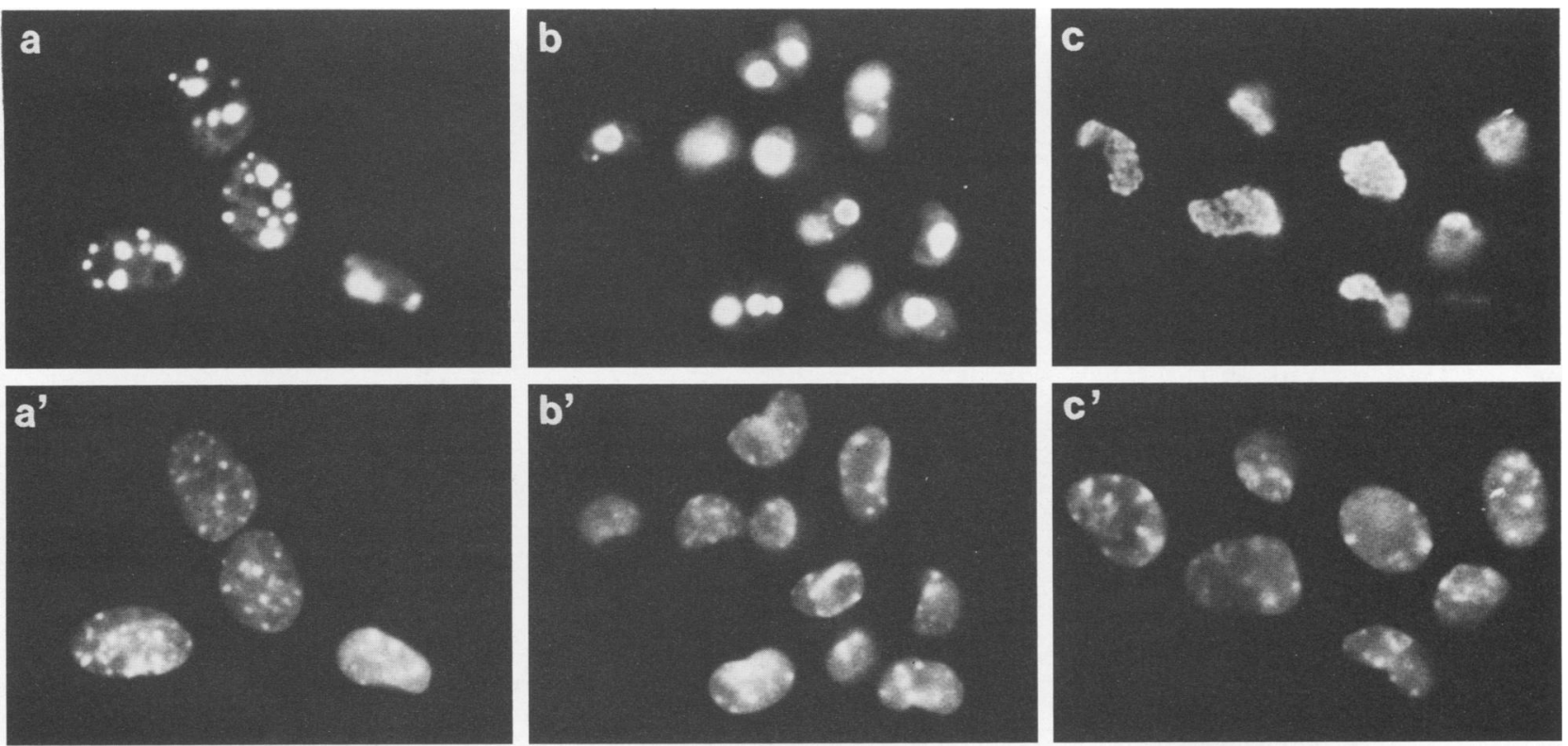

FIG. 5. Intracellular distribution of the 36- to 38-kDa E proteins. MEF at $6 \mathrm{~h}$ (a and $\left.\mathrm{a}^{\prime}\right), 10 \mathrm{~h}\left(\mathrm{~b}\right.$ and $\left.\mathrm{b}^{\prime}\right)$, and $24 \mathrm{~h}$ (c and $\left.\mathrm{c}^{\prime}\right) \mathrm{p} . \mathrm{i}$. were used for indirect immunofluorescence with mAb 20/234/28. To show the location of the cell nuclei, cellular DNA was stained with Hoechst dye 33258. ( $a, b, c)$ Fluorescein isothiocyanate immunofluorescence micrographs. $\left(a^{\prime}, b^{\prime}, c^{\prime}\right)$ Hoechst dye fluorescence micrographs of the same fields (magnification, $\times 500$ ).

umented an accumulation of these proteins within nuclear inclusion bodies (Fig. 6).

Genomic localization of transcription unit e1. To map the region encoding the $36-$ to $38-\mathrm{kDa} \mathrm{E}$ proteins, E RNA was hybrid selected by MCMV DNA fragments and analyzed by in vitro translation. To obtain a high amount of E RNA coding for these proteins, the following schedule of inhibitor treatment was employed: cells infected in the presence of $\mathrm{CH}$ were kept with this inhibitor for $3 \mathrm{~h}$. A 10-min interval without $\mathrm{CH}$ then allowed the synthesis of IE proteins from the transcripts accumulated during the $\mathrm{CH}$ block, which in turn could induce E-gene expression. Thereafter, $\mathrm{CH}$ was added for another period of $3 \mathrm{~h}$ to accumulate $\mathrm{E}$ transcripts.

The genomic map positions of DNA fragments used for the hybrid selection experiments are shown in Fig. 7. Proteins translated in vitro from whole-cell or hybrid-selected RNA were analyzed before (Fig. 7a) and after (Fig. 7b) immunoprecipitation. After hybrid selection of RNA by plasmid pAM84-5 (9), representing the 10.5-kilobase-pair XbaI-HindIII subfragment (map units 0.709 through 0.753 ) of the HindIII F fragment, four proteins of $33,36,38$, and 46 $\mathrm{kDa}$ were synthesized in vitro (Fig. 7a, lane 3 ). The antiserum precipitated the 33-, 36-, and 38-kDa proteins (Fig. $7 \mathrm{~b}$, lane 3). These three proteins were not translated from RNA selected by either plasmid pAM84-3 (9), representing the 5.3-kilobase-pair HindIII-XbaI subfragment (map units 0.658 through 0.681 ) of the HindIII F fragment (Fig. 7a, lane 2) or by DNA sequences from map units 0.753 through 0.818 (data not shown). These results located coding sequences for the $36-$ to $38-\mathrm{kDa} \mathrm{E}$ proteins and a $33-\mathrm{kDa}$ protein between map units 0.681 and 0.753 . The $46-\mathrm{kDa}$ protein was detectable after in vitro translation of RNA selected by the plasmids mentioned above. Since it was also synthesized in vitro from RNA selected by plasmids containing the other cloned MCMV DNA fragments, the 46-kDa protein represents an artifact of the translation system (data not shown).

Within the region between map units 0.681 and 0.753 , hybridization of cDNA prepared from the E RNA used for hybrid selection was restricted to sequences between map units 0.709 and 0.721 , represented by the $X b a I-P s t$ fragment contained in plasmid pBB2.9 (data not shown). This indicated that the in vitro translated 33-, 36-, and 38-kDa proteins are derived from RNA species transcribed from this region. Transfection of $B A L B / c$ 3T3 cells with plasmid pBB2.9 led to stably transfected cell lines that express the 36- to $38-\mathrm{kDa} \mathrm{E}$ proteins, as demonstrated by Western blot analysis with mAb 20/234/28 (Fig. 7c, lane 1). This proved that the complete coding region of the $36-$ to $38-\mathrm{kDa} \mathrm{E}$ proteins, which is from now on referred to as transcription unit $\mathrm{e} 1$, is contained within the sequence between map units 0.709 and 0.721 . The Western blot analysis with anti-MCMV serum showed that the $33-\mathrm{kDa}$ protein is also encoded by this region but does not share the mAb 20/234/28-binding site with the other proteins (Fig. 7d, lane 1).

Northern blot hybridization of E RNA with plasmid pBB2.9 revealed a prominent RNA size class of $2.6 \mathrm{~kb}$ (Fig. $7 \mathrm{e}$, lane 2). On the original autoradiograph, a faint signal was seen also at the position of 3.0 kilobases $(\mathrm{kb})$ (not visible in Fig. 7). The amount of 2.6-kb RNA at different times after infection (Fig. 8) showed an expression kinetics that strictly correlated with the expression kinetics of the $36-$ to $38-\mathrm{kDa}$ E proteins seen in Fig. 2. The 3.0-kb RNA species was seen mainly at $2 \mathrm{~h}$ p.i. and quickly decreased afterward.

Nucleotide sequence and structural analysis of the transcription unit e1. The entire nucleotide sequence between map units 0.709 ( XbaI site) and 0.721 (PstI site) was determined (Fig. 9). Figure 10 shows the physical map and the experimental strategy employed for identification of the structural organization of that region.

The analysis of transcription unit e1 was performed by nuclease digestion experiments with either 5 '- or 3 '-endlabeled DNA fragments or evenly labeled cRNA transcribed in vitro by the SP6 polymerase. The boundaries of each exon 


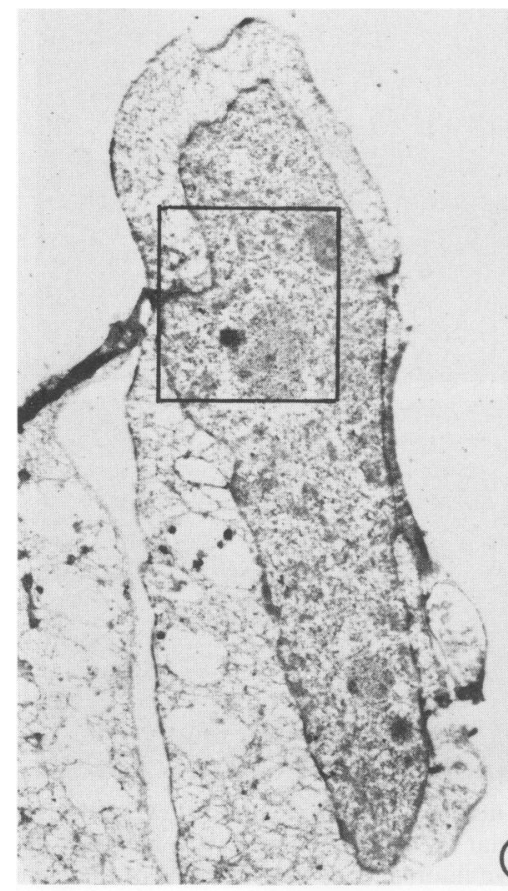

(a)
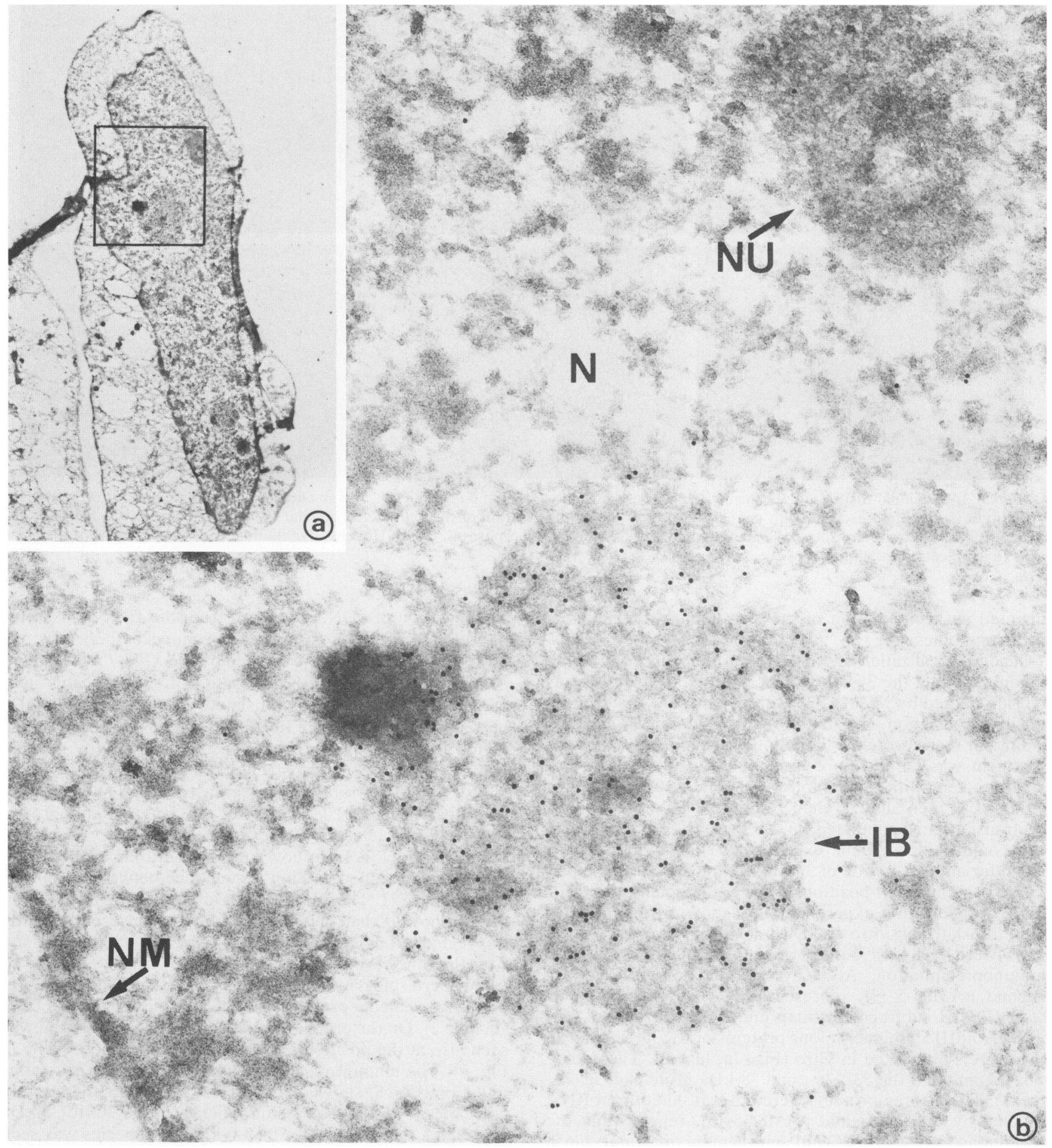

FIG. 6. Intranuclear distribution of the 36- to 38-kDa E proteins. Ultrathin frozen sections of MEF fixed at $12 \mathrm{~h}$ p.i. were incubated sequentially with $\mathrm{mAb} 20 / 234 / 28$, rabbit anti-mouse IgG, and protein A-colloidal gold particles. (a) Infected MEF (magnification, $\times 4,200$ ). (b) Framed area of the same cell (magnification, $\times 39,000$ ). The nucleus, nuclear membrane, nucleolus, and inclusion bodies are indicated by $\mathrm{N}$, $\mathrm{NM}, \mathrm{NU}$, and IB, respectively.

were determined with at least two different end-labeled DNA probes.

The position of the $5^{\prime}$-cap site of the el mRNA was mapped with the 330-nucleotide (n) XbaI-XhoI fragment (map units 0.709 to ca. 0.710). This fragment was $5^{\prime}$ end labeled at the XhoI site and hybridized to E RNA. After S1 nuclease digestion, two protected fragments of 189 and $176 \mathrm{n}$ were seen (Fig. 10A1, lanes b through d). No fragments were protected by mock RNA (Fig. 10A1, lane e). To test for the existence of two 5' termini of e1 mRNA, a 66-n XhoI-HaeIII fragment (map unit 0.710) was isolated after $5^{\prime}$ end labeling at the XhoI site and hybridized to E RNA. After extension of 


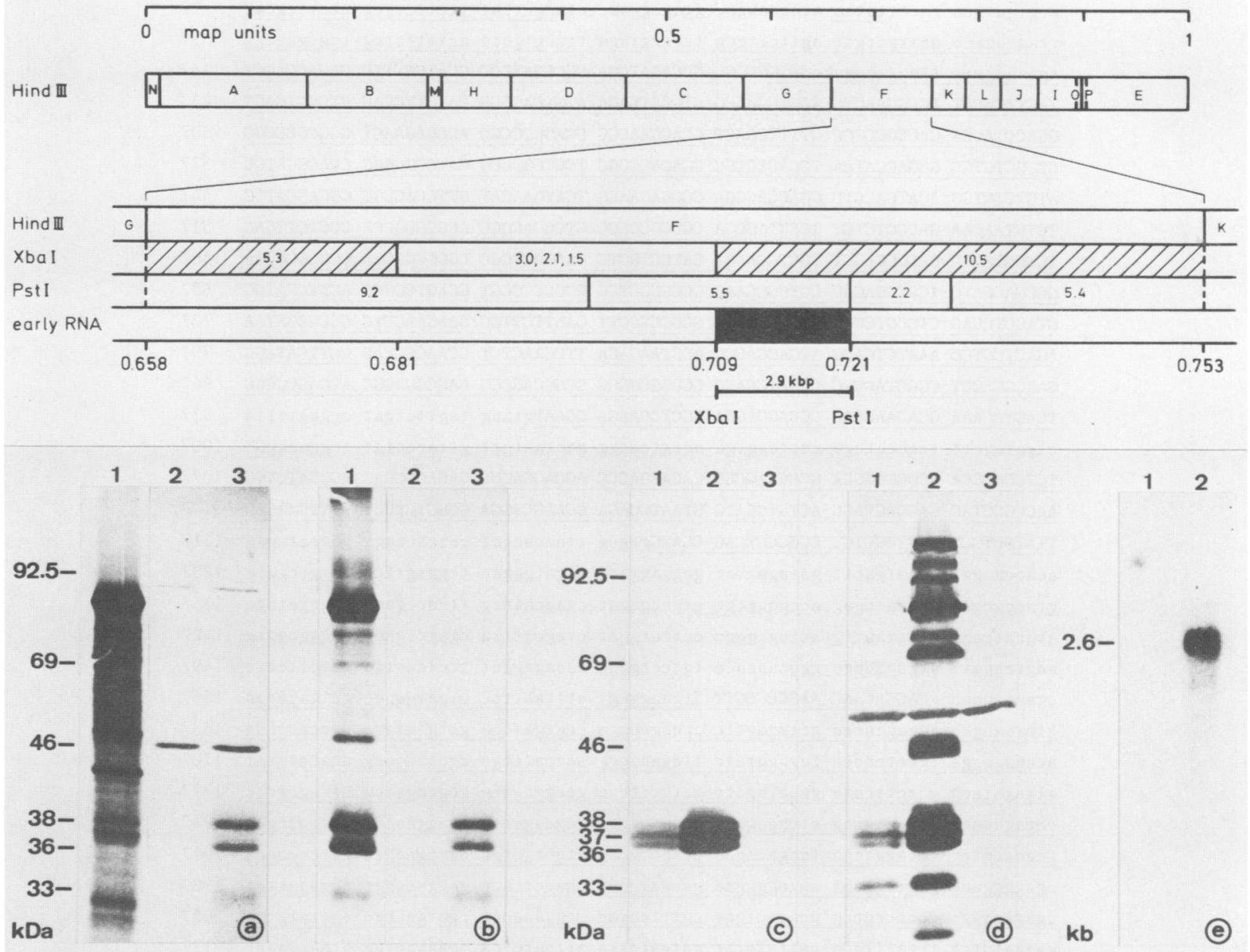

FIG. 7. Mapping of the coding region of the 36- to 38-kDa E proteins. At the top of the figure are shown the organization of the genome of MCMV strain Smith and a physical map for the HindIII fragments. The region between map units 0.658 and 0.753 is expanded, and $\mathrm{XbaI}$ and PstI sites within this region are shown. DNA fragments used for hybrid selection experiments are indicated by hatched bars. The black bar represents the DNA fragment contained in plasmid pBB2.9. ( $a$ and b) Coding sequences of the 36- to 38-kDa E proteins were mapped by analyzing in vitro translation products of E RNA hybrid selected by cloned DNA fragments. Shown are the proteins before (a) and after (b) immunoprecipitation with anti-MCMV serum. Lanes: 1, proteins from whole cell RNA; 2, proteins from RNA selected by the 5.3-kilobasepair (kbp) HindIII-XbaI subfragment of the HindIII F fragment (map units 0.658 to 0.681 ); 3, proteins from RNA selected by the 10.5 -kilobasepair HindIII-XbaI subfragment of the HindIII F fragment (map units 0.709 to 0.753). (c and d) Expression of the 36- to 38-kDa E proteins in cell line 65/3/2, which is stably transfected with pBB2.9, was analyzed by Western blotting with mAb 20/234/28 (c) and with anti-MCMV serum (d). Lanes: 1 , cell line 65/3/2 stably transfected with plasmid pBB2.9; 2, MCMV-infected BALB/c 3T3 cells at $16 \mathrm{~h}$ p.i.; 3 , mock-infected BALB/c 3T3 cells. (e) Transcripts synthesized from the region between map units 0.709 and 0.721 were determined by Northern blot hybridization with plasmid pBB2.9. Lanes: 1, mock RNA; 2, E RNA.

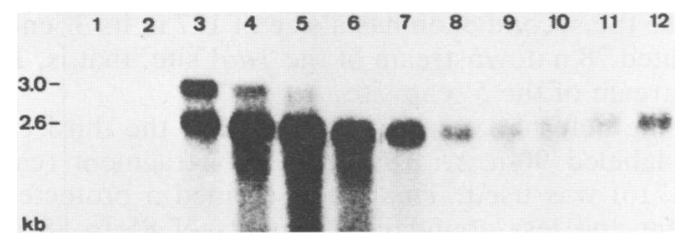

FIG. 8. Kinetics of expression of the 2.6-kb RNA. Samples $(5$ $\mu \mathrm{g})$ of whole-cell RNAs prepared from MEF at different times after infection were analyzed by Northern blot hybridization with a strand-specific ${ }^{32} \mathrm{P}$-labeled cRNA that was transcribed in vitro from map units 0.710 to 0.709 by the SP6 RNA polymerase. Lane 1 contained mock RNA. Lanes 2 through 12 contained RNA prepared from MEF at the following times p.i.: $2,1 \mathrm{~h} ; 3,2 \mathrm{~h} ; 4,3 \mathrm{~h} ; 5,4 \mathrm{~h} ; 6$, $6 \mathrm{~h} ; 7,8 \mathrm{~h} ; 8,10 \mathrm{~h} ; 9,12 \mathrm{~h} ; 10,16 \mathrm{~h} ; 11,20 \mathrm{~h} ; 12,24 \mathrm{~h}$. this primer by reverse transcriptase and separation of the extension products on sequencing gels, only the 189-n fragment could be detected (Fig. 10A1*, lane b). This result supported a single $5^{\prime}$ cap site of the e1 mRNA at $141 \mathrm{n}$ downstream of the $X b a I$ site and $24 \mathrm{n}$ downstream of the potential TATA box sequence TATAA.

By hybridizing E RNA to labeled cRNA transcribed from map units 0.715 (BstEII site) to 0.712 (XhoI site) and nuclease digestion, two fragments of 250 and $177 \mathrm{n}$ were detected; this indicated splicing (Fig. 10C, lane b). cRNA transcribed from the $X h o I$ site (ca. map unit 0.716) to the XhoI site at map unit $\mathbf{0 . 7 1 2}$ also protected the 250 - and $177-\mathrm{n}$ fragments and an additional fragment of about $85 \mathrm{n}$ (data not shown). This revealed the presence of at least two introns and three exons. The $3^{\prime}$ end of the first exon was located by hybridization of the $3^{\prime}$-end-labeled 842-n XhoI fragment (map units 0.712 to ca. 0.716) to E RNA. An S1-nuclease- 


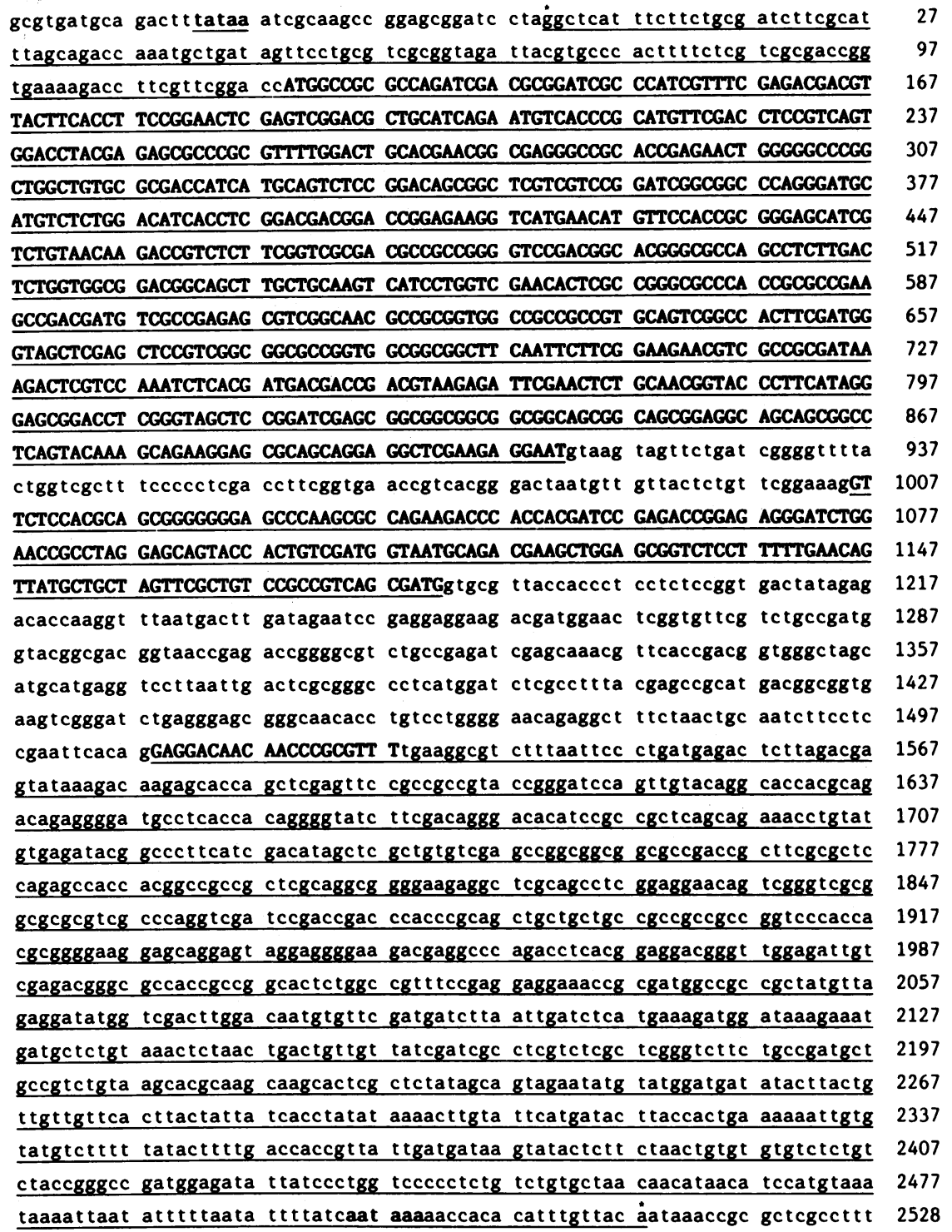

FIG. 9. Nucleotide sequence of the transcription unit e1. The nucleotide sequence from $43 \mathrm{n}$ upstream of the $5^{\prime}$ cap site to $19 \mathrm{n}$ downstream of the $3^{\prime}$ terminus of e1 is shown. Both termini are marked with asterisks. The TATA box sequence $28 \mathrm{n}$ upstream of the $5^{\prime}$ cap site and the polyadenylation consensus sequence $24 \mathrm{n}$ upstream of position $1,020 \mathrm{n}$ of the third exon are underlined and printed in boldface type. Noncoding exon sequences are only underlined. The predicted open reading frame of the spliced e1 mRNA is underlined and set in bold-faced capital letters.

resistant fragment of $250 \mathrm{n}$ (Fig. 10B1, lane b) determined the 3 ' end of the first exon adjacent to the splice donor consensus sequence GTAAGT $(26,32) 912 \mathrm{n}$ downstream of the 5' cap site of e1 mRNA.

The presence of a short second exon of $177 \mathrm{n}$ could be deduced from the nuclease protection experiments described above. To locate the $5^{\prime}$ end of this second exon, an S1 nuclease assay was carried out with a 5 '-end-labeled 149-n TaqI fragment (ca. map unit 0.714). Fragments of 105 and 99 n were protected (Fig. 10A2, lane b). A splice acceptor consensus sequence $(26,32)$ was only found adjacent to the 3 ' end of the 99-n fragment. The appearance of the 105-n protected fragment can be interpreted as a result of hybridization between sequences GGAAT (positions 908 to $912 \mathrm{n}$ ) at the $3^{\prime}$ end of the first exon and CCTTTC (positions 1,000 to $1,005 \mathrm{n}$ ) of the TaqI fragment preceding the $5^{\prime}$ end of the second exon. The 99-n fragment located the $5^{\prime}$ end of the second exon at $1,006 \mathrm{n}$ downstream of the $5^{\prime}$ cap site. Because the second exon has a size of $177 \mathrm{n}$, its $3^{\prime}$ end must be located $78 \mathrm{n}$ downstream of the TaqI site, that is, 1,182 $\mathrm{n}$ downstream of the $5^{\prime}$ cap site.

For the determination of the $5^{\prime}$ end of the third exon, a 5'-end-labeled 90-n XhoI-EcoRI DNA fragment (ca. map unit 0.716 ) was used. This probe defined a protected $87-n$ fragment and less abundant fragments of 85 to $88 \mathrm{n}$ (Fig. $10 \mathrm{~A} 3$, lane b). The only splice acceptor consensus sequence was located $85 \mathrm{n}$ upstream of the XhoI site. The size difference of $2 \mathrm{n}$ can be explained by imprecise $\mathrm{S} 1$ cleavage.

For the location of the $3^{\prime}$ end of the e1 mRNA, an S1 nuclease assay was carried out with the $3^{\prime}$-end-labeled AccI fragment (ca. map unit 0.720). Protected fragments of 108 and $121 \mathrm{n}$ (Fig. 10B2, lane b) indicated two possible $3^{\prime}$ ends 


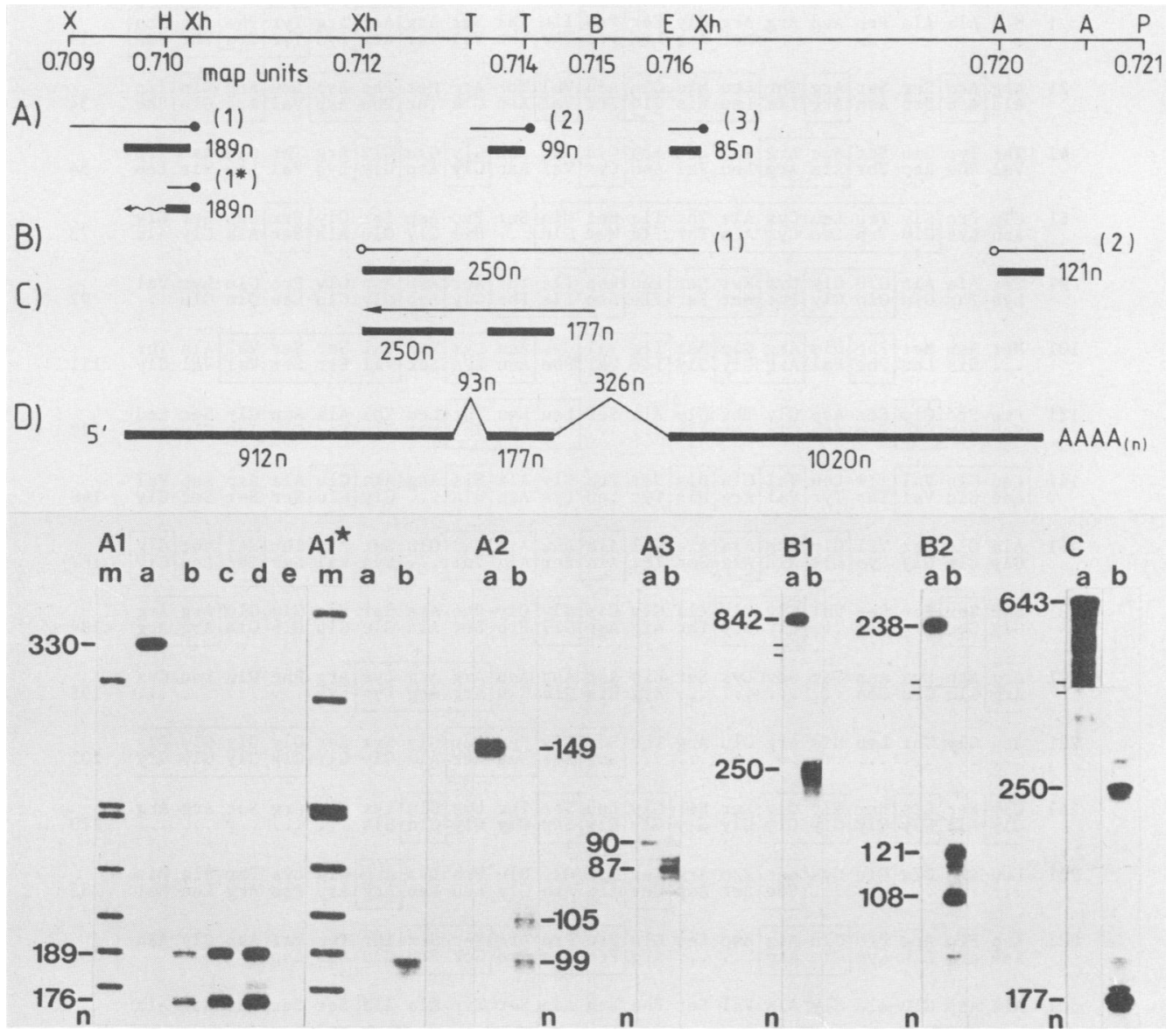

FIG. 10. Structural anaiysis of transcription unit e1. The experimental procedures for mapping the $5^{\prime}$ and $3^{\prime}$ ends of the e1 mRNA and for the location of exons are at the top of the figure. The experimental data are shown below. To present all relevant information in one figure, the autoradiographs were cropped and refitted as indicated. Restriction enzyme sites used for the characterization of the transcription unit: A, AccI; B, BstEII; E, EcoRI; H, HaeIII; P, PstI; T, TaqI; X, XbaI; Xh, XhoI. (Lines A through C) Whole-cell RNA from mock-infected and E-infected cells was hybridized to either 5'-end-labeled (line A, $O$ ) or 3'-end-labeled (line B, $O$ ) DNA fragments or to uniformly labeled cRNA (line C; the arrow shows direction and termination of cRNA transcription) and then incubated with S1 nuclease (lines A and B) or RNases $A$ and $T_{1}$ (line C). The heteroduplex formed after hybridization with the 66-n XhoI-HaeIII fragment at map units 0.710 ( $\left.A 1^{*}\right)$ was elongated with reverse transcriptase. The wavy line with the arrowhead indicates the size of the extended cDNA. Solid bars show the locations of protected fragments. The number of nucleotides is indicated. (Line D) Summary of the results. Shown at the bottom of the figure are autoradiographs of elongated (panel $\mathrm{Al}^{*}$ ) or protected fragments separated by electrophoresis in 60 -cm-long sequencing gels. With the exception of panel $\mathrm{Al}^{*}$, lanes a show the labeled fragments before the nuclease treatment, and lanes b show the nuclease resistant fragments after hybridization to E RNA at $44^{\circ} \mathrm{C}\left(30^{\circ} \mathrm{C}\right.$ in panel $\left.\mathrm{C}\right)$. In panel $\mathrm{Al}$, lanes $\mathrm{c}$ and d demonstrate the resistant fragments after hybridization to E RNA at 50 and $56^{\circ} \mathrm{C}$, respectively, and lane e shows protected fragments after hybridization to mock RNA. In panel $\mathrm{A} 1^{*}$, lane a shows the extended molecules from mock RNA, and lane b shows extended molecules from E RNA. In panels A1 and A1*, lanes m show size markers that were prepared by cleaving pBR322 with HpaII and labeling of the fragments at the $5^{\prime}$ ends. Additional size markers were from commercial suppliers.

2,515 and 2,528 $\mathrm{n}$ downstream of the $5^{\prime}$ cap site. Upstream of both putative $3^{\prime}$ ends, A+T rich sequences and AATAAA polyadenylation consensus sequences (32) are located, which leaves the possibility of two different $3^{\prime}$ ends.

Nuclease protection experiments that were performed with DNA fragments between map units 0.710 and 0.712 as well as between map units 0.716 and 0.720 did not indicate the existence of additional introns (data not shown). In conclusion, the e1 mRNA contains three exons of 912,177 , and 1,007 or $1,020 \mathrm{n}$, comprising $2.1 \mathrm{~kb}$. Introns are 93 and $326 \mathrm{n}$ in size. If the increase in size of mRNAs by polyadenylation is taken into account, the calculated length of the 2.1-kb e1 mRNA is in accord with the size of the 2.6-kb E RNA detected by Northern blot analysis.

The predicted E1 protein shows amino acid sequence ho- mology to a family of HCMV E proteins. The amino acid sequence of the E1 protein was deduced from the nucleotide sequence of the spliced e1 mRNA (Fig. 11). The first AUG, $39 \mathrm{n}$ downstream of the $5^{\prime}$ cap site, is followed by a stop codon UAG at position $63 \mathrm{n}$ and is not part of the consensus sequence $A / G N N A U G G$ of translation initiation (22). The second AUG at position $119 \mathrm{n}$ is contained in a consensus sequence of translation initiation and leads into an open reading frame of $990 \mathrm{n}$ that terminates with a UGA. The predicted protein of 330 amino acids has a calculated molecular mass of $36.4 \mathrm{kDa}$. It contains two glycine-rich sequences extending from amino acids 186 to 192 and 231 to 249. Computer-aided analysis with the Genetics Computer Group sequence analysis software package version 6.1 from August 1989 (7) detected similar glycine-rich regions in the 
1 Met Ala Ala Pro Asp Arg Arg Gly Ser Pro Tle Val Ser Arg Arg Arg Tyr Phe Thr Phe

21 Arg Asn Ser Ser Arg Thr Leu His GIn Asn Val Thr Arg Met Phe Asp Leu Arg GIn Trp

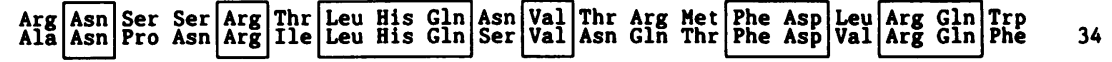

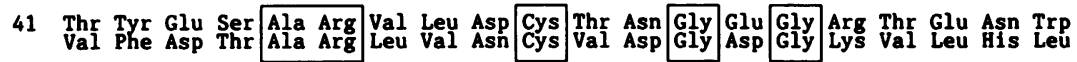

61 Gly Pro Gly Trp Leu Cys Ala Thr Ile Met Gln Ser Pro Asp Ser Gly Ser Ser Ser Gly

81 Ser Ala Ala Gln Gly Cys Met Ser Leu Asp Ile Thr Ser Asp Asp Gly Pro Glu Lys Val

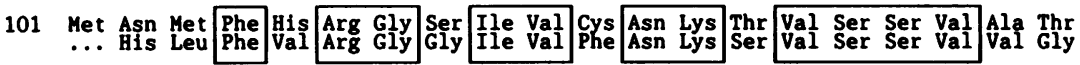

121 Pro Pro Gly Ser Asp Gly Thr Gly Ala Ser Leu Leu Thr Leu Val Ala Asp Gly Ser Leu

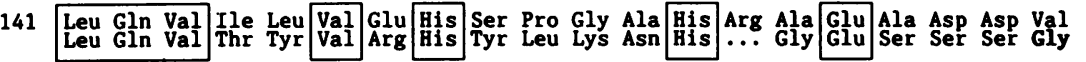

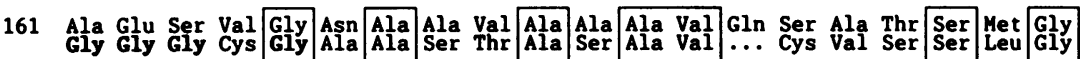

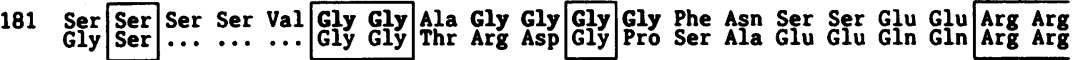
\begin{tabular}{l|llll}
\hline Arg Asp Lys Asp Ser Ser Lys Ser His Asp Asp Asp Arg Arg Lys & Arg Phe Glu Leu Cys \\
Arg Gin Glu GIn & $\ldots$ & $\ldots$ & $\ldots$
\end{tabular}

221 Asn Gly Thr Leu His Arg Glu Arg Thr Ser Gly Ser Ser Gly Ser Ser Gly Gly Gly Gly Ser ser ala Gly Gly Gy Gly Gly Gly

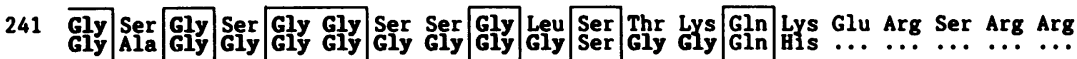
$261 \quad$ Leu Glu Glu Glu Cys Ser $\begin{aligned} & \text { Pro Arg } \\ & \text { Ser }\end{aligned}$

281 Asp Pro Arg Pro Glu Arg Asp Leu Glu Pro Pro Arg Ser Ser Thr Thr Val Asp Gly Asn 14

301 Ala Asp Glu Ala Gly Ala Val Ser Phe Leu Asn Ser Tyr Ala Ala Ser Ser Leu Ser Ala

321 Val Ser Asp Gly Gly Gln Gln Pro Ala Phe

FIG. 11. Comparison of the deduced amino acid sequences from the MCMV and HCMV E transcripts: alignment of the deduced amino acid sequence from e1 mRNA (above) and of the N-terminal region of the deduced amino acid sequence from the 2.2-kb HCMV transcript (below). Gaps were introduced into the HCMV sequence to generate maximum alignment of identical amino acids (boxed). The glycine-rich regions contained in both amino acid sequences are printed in boldface type. Amino acid positions of the MCMV and HCMV sequences are numbered on the left- and right-hand margins, respectively.

sequences of other polypeptides, for instance, the murine cytokeratin II (34), the Epstein-Barr virus nuclear antigen 1 (14), and the N-terminal region of the deduced amino acid sequences of a human cytomegalovirus (HCMV) 2.2-kb transcript that is encoded between map units 0.682 and 0.713 (33). Further significant homologies were only found with the deduced amino acid sequence of the HCMV transcript mentioned above. Optimal alignment of this HCMV amino acid sequence and the predicted MCMV e1 sequence revealed $30 \%$ identity (Fig. 11). In three regions spanning from amino acids 63 to 71,84 to 94 , and 104 to 118 , the identities were 100,72 , and $73 \%$, respectively. No homology to any other herpesvirus protein was seen.

\section{DISCUSSION}

In the present study the cell line B25, which expresses the ie1/ie3 gene complex of MCMV constitutively, was used to investigate the requirements for the induction of $E$-gene expression. Some E genes were induced by the IE proteins synthesized in B25 cells, whereas expression of other E genes depended on proteins synthesized after infection of B25 cells.

Differences in the requirements for E-gene expression are not without precedent. Several herpes simplex virus type 1 (HSV-1) E genes, but not the E gene coding for the alkaline exonuclease, were induced after infection of cells that expressed the HSV-1 IE protein ICP4 constitutively. This indicated the contribution of proteins other than ICP4 to the full E-gene expression (28). Recent studies on the induction of HSV-1 E genes revealed that the IE proteins ICP0 and ICP4 are both independently able to activate transfected HSV-1 E genes. Both IE proteins can act synergistically, since the induction of $\mathrm{E}$ gene expression was better when ICP0 and ICP4 were present $(10,11,36)$. Analysis of temperature-sensitive and deletion mutants of the ICP4 gene showed that ICP4 is essential for the induction of E genes in HSV-1-infected cells $(4,27,29,39)$. ICP0 alone is not able to activate $E$ genes included in the viral genome $(4,5)$ and, in contrast to ICP4, is not essential for productive infection in cell culture $(31,35)$.

For HCMV it could be shown by transient expression assays that the IE2 proteins activate heterologous as well as homologous promoters. The IE1 proteins enhance this effect but are not able to act independently from the IE2 proteins $(3,15,37)$.

The experiments shown here document that proteins encoded by the ie $1 /$ ie 3 gene complex of MCMV can activate 
homologous promoters of $\mathrm{E}$ genes introduced into cells by infection. Genes in the ie $1 / \mathrm{ie} 3$ gene complex share the promoter region and the $5^{\prime}$ cap site $(8,19)$. The ie1 transcription unit codes for the major IE protein pp89 and a set of smaller IE proteins that are antigenically related to pp89 (19, 20). The ie 3 gene region contains at least one exon located downstream of ie1 (Messerle, personal communication). ie1 gene products that are constitutively expressed in the L-cell line $45 / 1$ activate a transfected heterologous promoter (21). A study on the functions of ie 3 gene products in isolation is under way. Establishment of permissive cell lines that constitutively express either IE1 or IE3 proteins and infection of these cells with MCMV will answer the question of whether the ie 1 or ie 3 gene product or products of both genes are required for the expression of $\mathrm{E}$ genes. Work in progress indicates that MCMV IE1 proteins alone are not sufficient for the induction of $\mathrm{E}$ genes.

Other IE genes or some $E$ genes could account for the induction of the $E$ genes that require protein synthesis for expression. A 43-kDa protein encoded by the ie 2 gene region was so far only detected after in vitro translation of hybridselected RNA (19). In a mutant virus the ie2 gene is dispensable for virus replication in cell culture (23), which excludes an essential function of the IE2 protein for induction of $\mathrm{E}$ genes. In addition to the abundantly transcribed ie1, ie2, and ie 3 gene regions, low-rate IE transcription from the HindIII fragments E and N was observed (17). The role of putative IE proteins encoded by this region remains to be investigated. We favor the interpretation that the $\mathrm{E}$ genes induced in B25 cells code for proteins that control the expression of the second subclass of $\mathrm{E}$ genes in a cascadelike fashion.

Transcription unit e1, a member of the first subclass of MCMV E genes, and its gene products were characterized. Polypeptides of 36 to $38 \mathrm{kDa}$ encoded by this gene region are antigenically related, since they share the epitope for the $\mathrm{mAb} 20 / 234 / 28$. That this protein family is associated with intranuclear inclusion bodies, which probably represent the sites of viral DNA replication and nucleocapsid assembly (2, 40), may indicate a possible regulatory function in the viral replicative cycle. The presence of one major RNA species of $2.6 \mathrm{~kb}$ in Northern blots and the structural organization of $\mathrm{e} 1$ suggest that these proteins originate from the same transcript. The heterogeneity in size may arise from different posttranslational modifications. These must occur immediately after translation, since no alteration in the relative amounts of the 36- to $38-\mathrm{kDa}$ E1 proteins could be detected in pulse-chase experiments.

The coding sequence of el was mapped at between map units 0.709 and 0.721 , in the proximity of the IE transcription units ie1, ie2, and ie3 (19). Analysis of the gene structure revealed three exons with an open reading frame predicting a polypeptide with a calculated molecular mass of $36.4 \mathrm{kDa}$.

Studies on the posttranscriptional regulation of HCMV gene expression have identified cis-acting signals consisting of short open reading frames (in the 5' leader sequence of an E transcript), which cause a delay in translation without influencing mRNA transport or stability $(12,13)$. It has been suggested that these signals impede the translation of downstream open reading frames. Remarkably, the $5^{\prime}$ leader of the MCMV e1 mRNA also contains an AUG codon that leads into a short open reading frame of eight codons; yet, the translation of e1 transcripts is not delayed. The 36- to $38-\mathrm{kDa} \mathrm{E} 1$ proteins are abundantly synthesized during the first few hours of the E phase, and transcription and translation are strictly correlated. The nucleotide sequences that flank an AUG start codon have an influence on the initiation of translation (22). In the $5^{\prime}$ leader of the posttranscriptionally regulated HCMV E transcript the sequences adjacent to the AUG codons, namely, CGGAUGG for the first and AAGAUGG for the second AUG (12), do in part conform to the consensus sequence A/GNNAUGG of translation initiation, whereas the sequence CAAAUGC in the 5' leader of the MCMV el mRNA lacks a consensus sequence. Therefore our data do not formally contradict a potential role of signals in the 5' leader of HCMV transcripts.

Interestingly, after having established the el gene structure and the amino acid sequence of the predicted E1 protein, a $30 \%$ identity with the deduced $\mathrm{N}$-terminal amino acid sequence encoded by an HCMV E transcription unit that is located between map units 0.682 and 0.713 was found (33). Like transcription unit e1 of MCMV, this E transcription unit of HCMV is composed of three exons and is located in the proximity of IE transcription units. Antigenically related proteins of $34,43,50$, and $84 \mathrm{kDa}$ translated from differently spliced transcripts are phosphorylated and associated with the nuclear fraction of infected cells $(41,42)$. The 43-kDa protein is derived from an mRNA spliced after excision of both introns, as it is the case also for the 36- to 38-kDa E1 proteins of MCMV. Unlike the 43-kDa HCMV E protein and the 36- to $38-\mathrm{kDa} \mathrm{E} 1$ proteins of $\mathrm{MCMV}$, the 34-kDa E protein of $\mathrm{HCMV}$ is derived from an unspliced transcript. From this, one can conclude that the $43-\mathrm{kDa}$ protein rather than the $34-\mathrm{kDa}$ protein of $\mathrm{HCMV}$ is the counterpart of the $36-$ to $38-\mathrm{kDa}$ MCMV E1 proteins.

In addition to the 36- to $38-\mathrm{kDa} E 1$ proteins of MCMV detectable with $\mathrm{mAb} 20 / 234 / 28$, a $33-\mathrm{kDa}$ protein was seen with antiserum in the Western blot from cells transfected with plasmid pBB2.9 containing the region between map units 0.709 and 0.721 . This $33-\mathrm{kDa}$ protein was also found in cells infected with a recombinant vaccinia virus expressing the e1 coding region under the control of the vaccinia virus promoter. Again, the 33-kDa protein was recognized only by antiserum, not by mAb 20/234/28 (Messerle, personal communication). Because splicing of vaccinia virus-encoded transcripts is precluded, it follows that the $33-\mathrm{kDa}$ protein is derived from an unspliced transcript of e1. The 3.0-kb transcript of low abundance is likely to represent this unspliced transcript. Like the HCMV E coding region, the MCMV e1 sequence has an open reading frame that is terminated within the first intron at a position $914 \mathrm{n}$ downstream of the $5^{\prime}$ cap site and that encodes a predicted protein with a calculated molecular mass of $29 \mathrm{kDa}$, which is well in accord with the detected protein with an apparent molecular mass of $33 \mathrm{kDa}$. This would also mean that the antiserum detects epitopes specified by the first exon of $\mathrm{e} 1$, whereas binding of the mAb 20/234/28 depends on the expression also of the other exons. Collectively, the data suggest that the 33-kDa E1 protein of MCMV is the homolog of the 34-kDa E protein of HCMV. MCMV counterparts of the HCMV E proteins of 50 and $84 \mathrm{kDa}$ were not detected.

Even though the 36- to $38-\mathrm{kDa}$ E1 proteins of MCMV and the 43-kDa protein of HCMV appear to be homologous proteins, there is a significant difference in their kinetics of expression. Whereas the synthesis of the $36-$ to $38-\mathrm{kDa}$ E1 proteins is drastically reduced after the initial stages of the $E$ phase, the 43-kDa E protein of HCMV is relatively constantly synthesized throughout the $E$ and $L$ phases of the viral replication cycle $(41,42)$. This indicates that the two transcription units are differently regulated.

The function of these genes is not yet resolved, but a role in the regulation of subsequently expressed $E$ genes can be 
presumed. The 36- to 38-kDa E1 proteins of MCMV were shown to be very stable and could therefore perform their function also at later stages. Whether the differences in the kinetics of expression reflect differences in the function of these homologous proteins is open to question. The isolation of the e1 gene offers the possibility of studying the mechanism of transcriptional regulation by IE proteins and the role of the E1 proteins in the cascade regulation of the viral replicative cycle.

\section{ACKNOWLEDGMENTS}

We thank D. H. Spector for communication of unpublished results on the E transcription unit of HCMV and I. Bennett for typing the manuscript. The technical assistance from $\mathrm{H}$. Riehle, A. Schroeder, and A. Straubinger is acknowledged. We also thank M. J. Reddehase and K. Münch for helpful comments on the manuscript.

This investigation was supported by SFB 322 grant A7 from the Deutsche Forschungsgemeinschaft to U. H. Koszinowski.

\section{LITERATURE CITED}

1. Bertholet, C., E. Van Meir, B. ten Heggeler-Bordier, and R. Wittek. 1987. Vaccinia virus produces late mRNAs by discontinuous synthesis. Cell 50:153-162.

2. Cavallo, T., K. Graves, N. L. Cole, and T. Albrecht. 1981. Cytomegalovirus: an ultrastructural study of the morphogenesis of nuclear inclusions in human cell culture. J. Gen. Virol. 56:97-104.

3. Chang, C. P., C. L. Malone, and M. F. Stinski. 1989. A human cytomegalovirus early gene has three inducible promoters that are regulated differentially at various times after infection. $J$. Virol. 63:281-290.

4. DeLuca, N. A., A. M. McCarthy, and P. A. Schaffer. 1985. Isolation and characterization of deletion mutants of herpes simplex type 1 in the gene encoding immediate-early regulatory protein ICP4. J. Virol. 56:558-570.

5. DeLuca, N. A., and P. A. Schaffer. 1988. Physical and functional domains of the herpes simplex virus transcriptional regulatory protein ICP4. J. Virol. 62:732-743.

6. Del Val, M., K. Münch, M. J. Reddehase, and U. H. Koszinowski. 1989. Presentation of CMV immediate-early antigen to cytolytic $\mathrm{T}$ lymphocytes is selectively prevented by viral genes expressed in the early phase. Cell 58:305-315.

7. Devereux, J., P. Haeberli, and O. Smithies. 1984. A comprehensive set of sequence analysis programs for the VAX. Nucleic Acids Res. 12:387-395.

8. Dorsch-Häsler, K., G. M. Keil, F. Weber, M. Jasin, W. Schaffner, and U. H. Koszinowski. 1985. A long and complex enhancer activates transcription of the gene coding for the highly abundant immediately early mRNA in murine cytomegalovirus. Proc. Natl. Acad. Sci. USA 82:8325-8329.

9. Ebeling, A., G. M. Keil, E. Knust, and U. H. Koszinowski. 1983. Molecular cloning and physical mapping of murine cytomegalovirus DNA. J. Virol. 47:421-433.

10. ElKareh, A., A. J. M. Murphy, T. Fichter, A. Efstratiadis, and S. Silverstein. 1985. "Transactivation" control signals in the promoter of the herpesvirus thymidine kinase gene. Proc. Natl. Acad. Sci. USA 82:1002-1006.

11. Everett, R. D. 1986. The products of herpes simplex virus type 1 (HSV-1) immediate early genes 1,2 and 3 can activate HSV-1 gene expression in trans. J. Gen. Virol. 67:2507-2513.

12. Geballe, A. P., and E. S. Mocarski. 1988. Translation control of cytomegalovirus gene expression is mediated by upstream AUG codons. J. Virol. 62:3334-3340.

13. Geballe, A. P., R. R. Spaete, and E. S. Mocarski. 1986. A cis-acting element with the $5^{\prime}$ leader of a cytomegalovirus $\beta$ transcript determines kinetic class. Cell 46:865-872.

14. Hennessy, K., and E. Kieff. 1983. One of two Epstein-Barr virus nuclear antigens contains a glycine-alanine copolymer domain. Proc. Natl. Acad. Sci. USA 80:5665-5669.

15. Hermiston, T. W., C. L. Malone, P. R. Witte, and M. F. Stinski.
1987. Identification and characterization of the human cytomegalovirus immediate-early region 2 gene that stimulates gene expression from an inducible promoter. J. Virol. 61:3214-3221.

16. Honess, R. W., and B. Roizman. 1974. Regulation of herpesvirus macromolecular synthesis. I. Cascade regulation of the synthesis of three groups of viral proteins. J. Virol. 14:8-19.

17. Keil, G. M., A. Ebeling-Keil, and U. H. Koszinowski. 1984. Temporal regulation of murine cytomegalovirus transcription and mapping of viral RNA synthesized at immediately early times after infection. J. Virol. 50:784-795.

18. Keil, G. M., A. Ebeling-Keil, and U. H. Koszinowski. 1987. Sequence and structural organization of murine cytomegalovirus immediate-early gene 1 . J. Virol. 61:1901-1908.

19. Keil, G. M., A. Ebeling-Keil, and U. H. Koszinowski. 1987. Immediate-early genes of murine cytomegalovirus: location, transcripts, and translation products. J. Virol. 61:526-533.

20. Keil, G. M., M. R. Fibi, and U. H. Koszinowski. 1985. Characterization of the major immediate-early polypeptides encoded by murine cytomegalovirus. J. Virol. 54:422-428.

21. Koszinowski, U. H., G. M. Keil, H. Volkmer, M. R. Fibi, A. Ebeling-Keil, and K. Münch. 1986. The $89,000-M_{\mathrm{r}}$ murine cytomegalovirus immediate-early protein activates gene transcription. J. Virol. 58:59-66.

22. Kozak, M. 1984. Compilation and analysis of sequences upstream from the translational start site in eukaryotic mRNAs. Nucleic Acids Res. 12:857-872.

23. Manning, W. C., and E. S. Mocarski. 1988. Insertional mutagenesis of the murine cytomegalovirus genome: one prominent $\alpha$ gene (ie2) is dispensable for growth. Virology 167:477-484.

24. Marks, J. R., J. A. Mercer, and D. H. Spector. 1983. Transcription in mouse embryo cells permissively infected by murine cytomegalovirus. Virology 131:247-254.

25. Moon, H. M., V. J. Sapienza, R. I. Carp, and K. S. Kim. 1979. Murine cytomegalovirus-induced protein synthesis. J. Gen. Virol. 42:159-169.

26. Mount, S. M. 1982. A catalog of splice junction sequences. Nucleic Acids Res. 10:459-472.

27. Persson, R. H., and S. Bacchetti. 1987. In cell lines constitutively synthesizing a temperature-sensitive ICP4 protein of herpes simplex virus type 1 , amount and function of ICP4 are both regulated by temperature. Virology 158:285-293.

28. Persson, R. H., S. Bacchetti, and J. R. Smiley. 1985. Cells that constitutively express the herpes simplex virus immediate-early protein ICP4 allow efficient activation of viral delayed-early genes in trans. J. Virol. 54:414-421.

29. Preston, C. M. 1979. Control of herpes simplex virus type 1 mRNA synthesis in cells infected with wild-type virus or the temperature-sensitive mutant $t s K$. J. Virol. 29:275-284.

30. Reddehase, M. J., W. Mutter, K. Münch, H.-J. Bühring, and U. H. Koszinowski. 1987. CD8-positive T lymphocytes specific for murine cytomegalovirus immediate-early antigens mediate protective immunity. J. Virol. 61:3102-3108.

31. Sacks, W. R., and P. A. Schaffer. 1987. Deletion mutants in the gene encoding the herpes simplex virus type 1 immediate-early protein ICP0 exhibit impaired growth in cell culture. J. Virol. 61:829-839.

32. Sharp, P. A. 1981. Speculations on RNA splicing. Cell 23: 643-646.

33. Staprans, S. I., and D. H. Spector. 1986. 2.2-Kilobase class of early transcripts encoded by cell-related sequences in human cytomegalovirus strain AD169. J. Virol. 57:591-602.

34. Steinert, P. M., D. A. D. Parry, W. W. Idler, L. D. Johnson, A. C. Steven, and D. R. Roop. 1985. Amino acid sequences of mouse and human epidermal type II keratins of $M_{\mathrm{r}} 67,000$ provide a systematic basis for the structural and functional diversity of the end domains of keratin intermediate filament subunits. J. Biol. Chem. 260:7142-7149.

35. Stow, N. D., and E. C. Stow. 1986. Isolation and characterization of a herpes simplex virus type 1 mutant containing a deletion within the gene encoding the immediately early polypeptide Vmw110. J. Gen. Virol. 67:2571-2585.

36. Su, L., and D. M. Knipe. 1987. Mapping of the transcriptional initiation site of the herpes simplex virus type 1 ICP8 gene in 
infected and transfected cells. J. Virol. 61:615-620.

37. Tevethia, M. J., D. J. Spector, K. M. Leisure, and M. F. Stinski. 1987. Participation of two human cytomegalovirus immediate early gene regions in transcriptional activation of adenovirus promoters. Virology 161:276-285.

38. Walker, D., and J. Hudson. 1987. Analysis of immediate-early and early proteins of murine cytomegalovirus in permissive and nonpermissive cells. Arch. Virol. 92:103-119.

39. Watson, R. J., and J. B. Clements. 1980. A herpes simplex virus type 1 function continuously required for early and late virus
RNA synthesis. Nature (London) 285:329-330.

40. Weiland, F., G. M. Keil, M. J. Reddehase, and U. H. Koszinowski. 1986. Studies on the morphogenesis of murine cytomegalovirus. Intervirology 26:192-201.

41. Wright, D. A., and D. H. Spector. 1989. Posttranscriptional regulation of a class of human cytomegalovirus phosphoproteins encoded by an early transcription unit. J. Virol. 63:3117-3127.

42. Wright, D. A., S. I. Staprans, and D. H. Spector. 1988. Four phosphoproteins with common amino termini are encoded by human cytomegalovirus AD169. J. Virol. 62:331-340. 